\section{RESUME MATERI SISTEM INFORMASI MANAJEMEN KAMIS 25 APRIL 2019}

\author{
Jamaludin \\ 1711059013P \\ Fakultas Komputer \\ Mahasiswa@institusi.ac.id
}

\begin{abstract}
Sistem informasi manajemen merupakan bagian penting dalam mengelola dan menjalankan semua kegiatan. Satu di antaranya adalah sistem informasi manajemen Dalam memenuhi kebutuhan perusahaan untuk menangani masalah penjualan dan pembelian barang dan pembuatan laporan dan sistem penjualan dan pembelianya belum berjalan secara maksimal sesuai dengan yang diharapkan sehingga perusahaan membutuhkan sistem yang lebih baik dengan menggunakan sistem yang berbasis komputer. diharapkan akan mempermudah dan mempercepat proses pengolahan data penjualan dan pembelian barang dan pembuatan laporan dengan cara meminimalisasi atau bahkan menghilangkan kesalahan, sehingga sasaran dan tujuan prusahaan dapat tercapai secara maksimal.
\end{abstract}

\section{A. Tugas Seorang Manajer}

Yaitu mengelola sumberdaya agar dapat digunakan secara efektif untuk mengatur biaya, data dan mengelola sumberdaya.

\section{B. Tugas Direktur}

Mengetahui sistem yang ada di manajer dari direktur dan memberi kebijakan-kebijakan.

\section{Data Dan Informasi}

Data yaitu produk dan jasa:

- Jasa: Adalah setiap kegiatan atau manfaat yang ditawarkan oleh suatu pihak pada pihak lain dan pada dasarnya tidak berwujud, serta tidak menghasilkan kepemilikan sesuatu.

- Produk : Adalah sesuatu yang dapat ditawarkan ke pasar untuk diperhatikan, dipakai, dimiliki, atau dikonsumsikan sehingga dapat memuaskan keinginan atau kebutuhan.

\section{Bentuk sistem informasi}

1. Sistem informasi manajemen

2. Sistem informasi penunjang keputusan

3. Sistem informasi pakar

4. Sistem informasi transaksi

5. Sistem informasi exsekutif

6. Sistem informasi perkantoran

\section{E. Sistem informasi manajemen terdiri dari :}

1. Manusia: berperan sebagai pengguna sekaligus sebagai pengontrol sistem informasi.

2. Data dan informasi. 
Contoh :sistem informasi

perpustakaan.

3. Material : tidak hanya berupa bahan mentah saja tetapi dapat juga berupa biaya, data, informasi dll.

4. Manajemen informasi : berfungsi untuk mengelola sumber daya agar digunakan secara efektif.

Contoh :

a. Direktur mengetahui semua informasi yang di lakukan manajernya.

F. Sistem informasi vs teknologi informasi.

1. Sistem informasi :

Inplementasi dari data : manusia, material, biaya, mesin, uang, data dan informasi

Kombinasi prosedur kerja informasi, orang, teknologi kemudian dikumpulkan untuk mencapai sebuah tujuan organisasi.

2. Teknologi informasi :

Penerapan dari informasi

Mencakup perangkat keras, perangkat lunak, untuk melaksanakan tugas pemprosesan data untuk mentransmisikan sesuai prosedur.

\section{G. Perbedaan informasi dan informatika :}

1. Informasi : data yang sudah diolah

2. Informatika : informasi yang telah diterapkan. 